\title{
EMPATIA HISTÓRICA EM SALA DE AULA: RELATO E ANÁLISE DE UMA PRÁTICA COMPLEMENTAR DE SE ENSINAR/APRENDER A HISTÓRIA
}

\author{
HISTORICAL EMPATHY IN THE CLASSROOM: REPORT AND ANALYSIS OF A \\ COMPLEMENTARY PRACTICE TO TEACHING/LEARNING HISTORY
}

\author{
Breno Gontijo Andrade ${ }^{1}$ \\ Gilmar Rodrigues Júnior ${ }^{2}$ \\ Alexis Nascimento Araújo 3 \\ Júnia Sales Pereira ${ }^{4}$
}

\begin{abstract}
RESUMO: Esse artigo é o fruto de observações feitas nas aulas de História ministradas aos alunos do $8^{\circ}$ e $9^{\circ}$ ano no Centro Pedagógico - Escola de Educação Básica e Profissional da Universidade Federal de Minas Gerais - UFMG, e em outras escolas de Belo Horizonte, entre os anos de 2008 e 2009. A nossa proposta inicial era motivar os alunos em classe de maneira que eles sentissem maior interesse pela História, utilizando de estratégias didáticas diferentes daquelas comuns às aulas de História. A estratégia adotada foi o uso da Empatia Histórica, isto é, o exercício de colocar-se no lugar do outro vivente em um tempo diferente do seu. $O$ artigo explicita como essa estratégia foi utilizada e como os alunos responderam a ela.
\end{abstract}

Palavras-chave: Ensino de História. Empatia Histórica. Relato de Prática Pedagógica.

\begin{abstract}
This article is the result of observations made in the lessons of history taught to students of 8th and 9th grade in Centro Pedagógico - Escola de Educação Básica e Profissional da Universidade Federal de Minas Gerais UFMG, and other schools of Belo Horizonte, between the years 2008 and 2009. Our initial purpose was to motivate students in class so that they feel greater interest in History. For this, we used different teaching strategies from those common to traditional lessons in history. The strategy adopted was the use of Historical Empathy, i.e., the exercise of putting oneself in another's place in a time different from yours. The article explains how this strategy was used and how students responded to them.
\end{abstract}

Keyword: Teaching History, Historical Empathy, Reporting of Pedagogical Practice

\footnotetext{
${ }^{1}$ Mestrando em História e Culturas Políticas pela Universidade Federal de Minas Gerais UFMG

${ }^{2}$ Graduado em História pela Universidade Federal de Minas Gerais UFMG

${ }^{3}$ Graduado em História pela Universidade Federal de Minas Gerais UFMG

${ }^{4}$ Professora Adjunta da Graduação e Pós Graduação em Educação UFMG
} 
O senhor diz que uma sólida educação é tudo o que espera que a criança receba da escola. Mas o que se entende por educação? Antigamente, tratava-se em essência de um processo verbal; quer dizer, uma criança poderia aprender de cor tudo aquilo que uma enciclopédia contém e, desse modo, saberia tanto mais do que a escola seria capaz de lhe oferecer. Mas, doutor Hummer, é necessário que o senhor se dê conta de que, para a préadolescente dos dias hoje, os programas pedagógicos tem menos validade existencial do que os programas de fim de semana (piscadela de olhos), para repetir o jogo de palavras que a psicanalista da Universidade de Beardsley se permitiu fazer outro dia. Vivemos não apenas no mundo de ideias, mas também num mundo de coisas. Quando não se baseiam em experiências concretas, as palavras perdem todo o significado. A troco de que nossa Dorothy Hummerson haveria de se preocupar com a Grécia e o Oriente, com seus haréns e escravos?

Lolita (Vladimir Nabokov)

\section{Introdução}

O presente artigo se divide em quatro partes principais. A primeira parte é composta por uma breve discussão acerca do nosso entendimento sobre o ensino de História na atualidade. A segunda parte trata da sistematização de estratégias metodológicas orientadas pelo princípio da empatia história, que utilizamos para sensibilizar, ensinar e motivar os alunos em sala de aula, enquanto a terceira parte traz o relato da aplicação destas estratégias, de como os alunos entraram em contato com elas e quais foram suas primeiras respostas. Por fim, na última parte há algumas considerações sobre o processo experienciado.

Partimos do pressuposto de que os convencionais métodos de ensino, caracterizados principalmente pela transmissão de uma enorme quantidade de conteúdos, muitas vezes descontextualizados da realidade dos aprendizes, não dão conta de se adequar aos novos ritmos da sociedade de nossos dias. Nessa sociedade, a informação - de qualidade ou não - é cada vez 
mais acessível à grande parte da população, inclusive aos alunos, que desenvolvem novos ritmos de aprendizagem. Para esses discentes, as tradicionais aulas expositivas e transmissivas, centradas no saber docente, e desprovidas de cargas experienciais, geralmente, são monótonas e não instigam tanta curiosidade se compararmos a outras estratégias didáticas. Um grande desafio para os docentes, atualmente, é despertar a atenção de seus alunos para a aprendizagem, tornando a História um saber participante de suas realidades.

Tendo como foco as aulas de História, buscaremos com esse artigo, de forma bastante panorâmica, caracterizar a situação atual do ensino de História no Brasil e expor pressupostos que orientaram uma experiência de prática pedagógica, expostos aqui como uma das alternativas para um ensino de História em perspectiva renovada, sobretudo para alunos do final do antigo ensino fundamental e início do ensino médio.

Como então ensinar História de maneira que resulte em envolvimento dos estudantes e em um aprendizado significativo? Hoje em dia, recursos tecnológicos não faltam, o que podemos dizer que já se trata de um avanço nas práticas de ensino, entretanto, essas ferramentas devem ter um sentido e momentos certos para serem utilizadas. A utilização das mesmas, de forma mecânica e acrítica, também pode resultar em aulas monótonas e regidas por parâmetros da transmissão, nas quais há substituição do quadro negro e giz por computadores e projeções, mas o que orienta e fundamenta as aulas permanece: falta de contextualização, baixa interatividade entre os sujeitos envolvidos e deles com os materiais didáticos e temas em estudo, falta de vinculação com o universo de interesses dos alunos.

Mas, podemos nos interrogar se o alheamento dos alunos deve-se apenas ou sobretudo ao advento de novas tecnologias que tornariam a sala de aula lugar obsoleto. Receamos que a questão precisa ser colocada em outros patamares. Como convocar o pensar e sentir a história de modo a que os sujeitos sintam-se convocados, participantes? Que sensibilidades poderemos cultivar se os estudantes puderem experienciar realidades e percepções da história - pontos de vista - que não são os seus? 
É recorrente ouvirmos docentes apontarem que uma das grandes barreiras à aprendizagem hoje em dia é a falta de motivação dos discentes. Não queremos aqui entrar em questões pessoais de cada um deles em relação às causas de sua desmotivação, sabemos que elas existem, mas independente delas, buscamos propor um percurso metodológico que sensibilize e ao mesmo tempo estimule a participação dos alunos, de modo que eles interajam com o conhecimento histórico segundo seus questionamentos próprios. É importante lembrar que há muito já se tem mostrado que a sala de aula é heterogênea, e propostas que tendem a homogeneizá-la podem resultar em prejuízos para vários discentes, sobretudo aqueles que não são sensíveis a estratégias mais convencionais de ensino-aprendizagem. Por isso, nossa pesquisa também busca resgatar essa heterogeneidade existente em sala de aula. Uma das hipóteses deste trabalho é a de que a desmotivação em sala de aula com relação à História, em grande parte, se associa à falta de percepção dos alunos em entender que o conhecimento histórico diz respeito a eles. E não os culpamos por isso. Pode o professor explicitar a relação entre o conhecimento histórico e as realidades de cada aluno, criando abordagens que reconheçam a heterogeneidade de perfis discentes.

A partir dessas constatações, nos colocamos a seguinte questão: como podemos construir um conhecimento histórico em sala de aula em que haja participação efetiva - e não só teórica - dos discentes? Afirmamos que a construção de conhecimento, independente se ele é histórico ou não, requer, sobretudo, o exercício do desafio. O desafio pode convocar os discentes a pensar e à participação ativa. Acreditamos, ainda, que o conhecimento histórico deve ter alguma significação para os aprendizes, ou seja, pode fazer sentido para eles, e mesmo que não seja diretamente aplicável em suas vivências, que aprimore a capacidade de interpretar, pensar(se) e que desenvolva o senso crítico dos alunos. Em uma palavra, o ensino de História pode se orientar pelo propósito de formação de conhecimento da história pelos alunos, evitando conteúdos que sejam descontextualizados de suas vivências e estratégias que os concebam como meros receptores de narrativas das quais não participaram sujeitos. Uma educação histórica não se resume, pois, à acumulação de conhecimentos sobre o passado, mas ao de- 
senvolvimento da sua compreensão (BARBOSA, 2004, p. 199). Como fazer com que os discentes cultivem sensibilidades para com a vivência da história, se no momento da construção do conhecimento, há pouca aproximação com a realidade dos aprendizes? O estudo aqui desenvolvido vai ao encontro dessa aproximação entre o saber histórico e a realidade dos alunos, orientada pelos pressupostos da empatia.

Nesse caso, consideramos como empatia, o seu próprio sentido stricto, isto é, a capacidade de um sujeito ${ }^{5}$ se colocar no lugar de outro, de tentar pensar e ver o mundo com outros olhos, outras mentalidades, ainda que esses sujeitos sejam separados por longo período temporal. Segundo Pierre Rosanvallon, a empatia, contrariamente à simpatia, não implica nenhuma identificação. Para se pensar empaticamente, há o exercício de um trabalho de informação, isto é, a avaliação de situações a partir de supostas maneiras de pensar e agir do outro e de um trabalho de distanciamento, isto é, a avaliação entre a diferença de minha própria situação e a do observado. A empatia é em sua essência, especulativa ${ }^{6}$. (ROSANVALLON, 1996, p. 35). O que relataremos a seguir, vinculado ao uso da noção de empatia na aula de história, tem relação com dois movimentos: descentramento e imaginação. Quanto ao descentramento, trata-se do afastamento do sujeito dos seus próprios e particulares pontos de vista, de suas percepções sobre ser e viver no tempo presente. Ao deslocar-se para outro tempo, experienciando outra posição no mundo, o aluno poderá vivenciar e adquirir compreensão acerca da falibilidade e da redutibilidade de seus pontos de vista (deles em relação a todo um universo plural e mutável de outros pontos de vista, no presente e no tempo). Poderá também exercer a imaginação, pois será convocado a criar mundos históricos do qual participará como ator.

No que diz respeito à empatia histórica em sala de aula, Samuel Wineburg dirá que os alunos, ao criarem uma relação empática com os persona-

\footnotetext{
${ }^{5}$ Entendemos a história como algo feito pelos sujeitos, seja pelos seus participantes diretos, isto é, que a vivenciaram em dado momento, seja pelos seus participantes indiretos, isto é, aqueles que a herdaram e a utilizam de alguma forma.

${ }^{6}$ Peter Lee e Rosalyn Ashby pensam a empatia de uma forma bastante ampla. Segundo os autores a empatia é: a capacidade de perceber algo condicionalmente apropriado, as ligações entre intenções, circunstâncias e ações e, finalmente, a capacidade de perceber como uma perspectiva particular seria realmente afetada por ações em circunstâncias particulares (LEE \& ASHBY, 2001, p. 25).
} 
gens do passado, fazem-no através de lentes da sua contemporaneidade, atitude a que ele chamou de "presentismo"7 (WINEBURG, 1994, p. 157). Não cabe nesse artigo discussões historiográficas acerca da realidade do passado. No entanto, estamos alinhados com os postulados que nos informam sobre a impossibilidade de conhecer o passado tal como ele foi. Ao usar a empatia, sabemos que o colocar-se no lugar do outro é, em termos historiográficos, uma mera ilusão, posto que o passado é uma eterna construção do nosso presente, e dos presentes que ainda virão. Dessa forma, o passado tal como foi, é inatingível em sua totalidade. O historiador ao tocálo contamina-o com a virulência do presente. Avaliamos que, em sala de aula, também o fazem assim os estudantes e o professor: há aproximações e usos do passado no presente, operação mediada por percepções, tensões e pontos de vista dos sujeitos viventes. Então, em termos educacionais, o exercício orientado e fundamentado da empatia poderá convocar os sujeitos aos descentramentos necessários à aprendizagem da cultura e da história.

Feita as considerações sobre a empatia histórica, passaremos a seguir ao relato de experiência prática orientada pelo pressuposto da Empatia, considerada, por nós uma Prática Complementar de se Ensinar/Aprender a História. O uso da palavra Complementar não é aleatório, pois essa proposta não ambiciona abolir com a maneira usual ${ }^{8}$ de se ensinar História, mas procurou, em um primeiro momento, demonstrar outras opções de se ensinar/aprender a pensar a História.

\section{Sobre a Prática Complementar de se Ensinar/Aprender a História}

Optamos por sistematizar um roteiro de ações orientado metodologicamente, que consideramos seja Complementar, para que se possa enten-

\footnotetext{
7 Há diversos artigos sobre o uso da empatia na educação, mas, geralmente, se orientam mais pelo exercício de pensar as operações mentais dos discentes do que pela sua prática em sala de aula.

${ }^{8}$ Entendemos que a realidade nas escolas públicas brasileiras (salas lotadas, alunos sem apoio familiar, recursos precários, descaso governamental, salários humilhantes aos professores, etc) contribuem significativamente para que inovações no ensino sejam de dificílima implementação. Entretanto, o presente artigo volta-se sobre outras possibilidades de atuação docente marcadamente interativas, dinâmicas e propositivas, evidentemente apontando seus limites, mas também suas potencialidades.
} 
der todo o processo de criação e execução desse tipo de aula. Após a sua sistematização e alguns comentários, o seu funcionamento será demonstrado através da narração de uma aula verídica que se valeu desta estratégia. Foram desenvolvidas cinco etapas na experiência aqui imaginada e depois vivenciada e relatada:

10- Identificar o que se quer ensinar

20- Criação de Situações de Aprendizagem

30- Exposição da Situação de Aprendizagem

40- Interpretação da Situação de Aprendizagem

50- Discussão sobre as interpretações

\section{0- Identificar o que se quer ensinar}

Quando íamos ministrar as aulas, nesse momento traçávamos os objetivos gerais dos conteúdos que pretendíamos ensinar aos alunos. É somente através desses objetivos que o método começa a ser construído e, efetivamente, passa a ter sentido, tornando-se útil ao aprendizado dos discentes e deles, no processo interacional próprio à sala de aula, com o professor.

20- Criação de Situações de Aprendizagem

Nessa fase utilizávamos da criatividade para a elaboração escrevendo as situações de aprendizagem que serviriam para ensinar os alunos a pensar, sentir e viver a História por meio do recurso da Empatia. Essa parte era a mais difícil da nossa prática, não porque ela fosse mais complexa, mas pela própria limitação que a escrita impõe, às vezes, às explicações que poderiam ser facilmente entendidas se fossem faladas.

Mas o que são as situações de aprendizagem? As situações de aprendizagem são experiências históricas que o professor cria para que os alunos, empaticamente, as vivencie. Essas experiências são baseadas na História ${ }^{9}$ e não em invenções disparatadas, pois o objetivo da aula, neste caso, é a vivência, sentimento e percepção de um conhecimento histórico, de modo encarnado pelos alunos, rompendo com o alheamento do conhecimento pelos mesmos, mas vinculando-os às formas narrativas da história.

\footnotetext{
${ }^{9} \mathrm{O}$ que recomendamos é que a ação docente pode/deve se basear no conhecimento histórico construído ao longo do tempo - ainda que construa situações hipotéticas - e não em criações fantasiosas sem nenhum paralelo com a História.
} 
Como elaboramos, na experiência aqui relatada, essas situações de aprendizagem?

Consideramos que é necessário que elas sejam imaginadas e depois escritas. Como exemplo para se compreender essa fase, suporemos que um professor hipotético desejasse desenvolver o assunto Revolução Francesa com uma turma. Um dos vários objetivos gerais que ele traçou na primeira etapa foi demonstrar aos alunos que a fome motivou considerável parte da população pobre de Paris a atuar contra o governo de Luís XVI. Com esse objetivo geral o professor passa para a segunda etapa, que tem por fim criar situações históricas para que os alunos a experimentem. No caso, o professor começou a criar uma situação de aprendizagem que envolvesse os alunos na questão da fome que ocorria na França ${ }^{10}$.

O professor hipotético então imagina o seguinte roteiro: Seca e adversidades naturais na França - baixa produção dos camponeses - encarecimento do trigo - trigo é vendido a altos preços em Paris - padeiros começam a aumentar o preço do pão - encarecimento do pão - diversas famílias em Paris não conseguem se alimentar por conta dos altos preços - reações da população. Seguindo essa lógica, escreve a seguinte situação de aprendizagem:

Vocês (toda a sala) são um grupo de camponeses que vivem em uma região da França desde que nasceram. Assim como foi com os seus avós, sempre que colhiam, pagavam impostos ao senhor nobre dono da terra. Todos os anos, além dos impostos, vocês tinham que sustentar suas famílias e ainda restava-Ihes uma pequena parte da colheita que vocês costumavam vender para alguns comerciantes que visitavam a região esporadicamente. Há muito tempo, vocês criaram o costume de vender pouco mais ou menos que 8 sacas de trigo para os comerciantes, das 30 que costumavam colher. Para manterem a família de vocês 21 sacas bastavam. Os comerciantes pagavam no máximo 3 moedas por saca. Assim, em um ano normal de colheita, vocês consumiam as 21 sacas, alimentando-se e pagando algumas taxas, e conseguiam na venda das 8 sacas que sobravam, 24 moedas. Esse ano vocês experimentaram uma adversidade jamais vista.

${ }^{10}$ Ainda que essa sensação seja ilusória. 
Perceberam que houve uma grande seca na região que prejudicou a colheita, pois colheram muito menos do que estavam acostumados. Vocês colheram cerca de 23 sacas por família, isto é, sobraram duas sacas para venderem, ao contrário das 8 sacas que restavam quase todos os anos. Vocês souberam por boatos que alguns camponeses de terras próximas, haviam colhido muito menos, e que por isso não venderiam o que tinham, pelo fato de possuírem apenas o necessário para se manterem. Alguns entre vocês estavam na dúvida de vender as sacas para os comerciantes, pois o ano que viria poderia ser até pior que esse, levando todos à temida fome. Chega o período em que os comerciantes vêm comprar o excedente de vocês, nesse ano de más colheitas. Como vocês têm duas sacas apenas para vender por família, eles pedem que vocês vendam mais seis, para que se complete as oito sacas que eles costumam comprar todos os anos. Como vocês pretendem comercializar com os negociantes?

30- Exposição da Situação de Aprendizagem

Após a criação de uma situação de aprendizagem, tal como a situação supracitada, consideramos, no âmbito da experiência relatada, que é necessário expô-la aos alunos. Primeiramente, a exposição exige um exercício de cunho antropológico, pois consiste em que os alunos estejam desprovidos de toda a realidade do presente, pratiquem o necessário descentramento cultural. Está neste caso previsto um exercício imaginativo a respeito de como viveram personagens em outro tempo histórico. Um dos prérequisitos para este descentramento é a ambientação dos alunos na época. Essa ambientação pode se iniciar com simples estratégias, como no caso do professor tratar os alunos por camponeses. Uma estratégia que utilizamos nas escolas, nesta experiência, foi a descrição dos hábitos da sociedade estudada, suas crenças, como vestiam, quem eram, e também alguns recursos audiovisuais - considerados mediadores culturais, quando esses existiam, tais como imagens, músicas e trechos de filmes sobre a época estudada. Esses mediadores culturais proporcionaram significativo efeito entre os alunos e em pouco tempo eles começavam a se inspirar e se identificar com hábitos, modos de vida e costumes dos personagens pretéritos. Ao mesmo tempo que criávamos esse efeito, narrávamos a situação de aprendizagem 
que os discentes deveriam enfrentar e dessa maneira exercer princípios da construção do conhecimento histórico.

40- Interpretação da Situação de Aprendizagem

Após a exposição da situação de aprendizagem, estimulávamos os discentes a entender a proposta, interpretando-a e buscando solucioná-la por meio de seu conhecimento prévio em História. Quando utilizávamos destas estratégias, os alunos se viam diante de um problema histórico para resolver, o qual deveria ser solucionado através da vivência empática. Vale ressaltar que nas situações de aprendizagem os alunos têm oportunidade de vivenciar coletivamente os desafios de elaboração do conhecimento histórico na medida em que se esforçam empaticamente para solucionar um problema. Nas situações vividas por nós, como docentes, sempre que os alunos resolviam determinadas situações de aprendizagem, como professores nós intervínhamos acrescentando outros saberes, associando o episódio que eles enfrentavam a outros desdobramentos da disciplina. Após esse procedimento, prosseguíamos com outras narrações, outras situações de aprendizagem, para novas soluções. Porém, nem sempre os aprendizes obtinham sucesso em suas interpretações, formulando hipóteses absurdas ou anacrônicas. O exercício, contudo, de formulação de soluções introduz significativamente os estudantes no universo do pensar histórico, mesmo que os resultados sejam insatisfatórios. Neste caso, vale notar que o processo vivenciado é tão significativo quanto os resultados finais.

Mas não custa ressaltar que é necessário o diálogo permanente com os alunos durante o processo. No caso de interpretações equivocadas, isto é, uma interpretação totalmente incoerente e absurda para a ocasião histórica, nós alimentaríamos o diálogo com outras informações e conduziríamos o debate para possíveis e plausíveis soluções do problema. Esses equívocos podem ser observados na situação de aprendizagem sobre a fome em Paris, que acabamos de explicitar. Suponhamos que, no fim da situação de aprendizagem - exemplificada na etapa dois - quando o professor pergunta como vocês pretendem comercializar com os comerciantes? os discentes não consigam solucionar o problema histórico respondendo algo do tipo vendemos todas as sacas para os comerciantes ou vendemos a metade das sacas para 
os comerciantes. Certamente, essa ação comprometeria a própria existência dos camponeses, o que nos faz pensar que, dificilmente algum camponês agiria da forma que os alunos propuseram. Quando os alunos não conseguiam agir empaticamente, tentávamos introduzir outros elementos no debate entre eles e reconduzir a interpretação sobre aquela realidade, com dados e ponderações de natureza histórica que proporcionassem soluções mais coerentes. Para isso, no exemplo que estamos utilizando, poderíamos lançar perguntas à sala com o intuito de abalar a interpretação dos alunos, tais como: por que vocês acham que os camponeses venderiam toda suas sacas aos comerciantes, sendo que se produziu pouco trigo e vocês precisam dele para se alimentar? ou o que vocês fariam com todo esse dinheiro, sendo que no dia seguinte não haveria trigo para a alimentação de vocês? ou por que um camponês que pensa no seu sustento e na de sua família, não guardaria o que havia plantado?. Perguntas como essas, lançadas durante a experiência fictícia relatada, fariam provavelmente com que os discentes repensassem suas interpretações sobre as situações propostas, podendo chegar a respostas historicamente mais plausíveis.

50- Debate sobre interpretações

Após a solução das situações de aprendizagem, iniciávamos um rápido debate com os discentes. Explicamos melhor o porquê de determinadas ações serem mais plausíveis do que outras em determinado tempo. Tudo isso contribuiu para a fixação da experiência que os alunos acabavam de vivenciar. O ato de não comentar as interpretações realizadas em sala de aula, era evitado, pois, do contrário, as situações de aprendizagem virariam um amontoado de etapas, as quais os alunos por tentativa e erro podiam superar. Por isso, buscávamos sempre nos certificar de que as ações tomadas pelos alunos foram historicamente conscientes e não baseadas no erro e acerto.

Basicamente, como a experiência narrada acima é um ensaio fictício, foi esse o caminho que trilharíamos para ministrar as aulas segundo esse formato. Para maior entendimento, e para avaliação das estratégias metodológicas e de seus pressupostos, agora passaremos para um relato verídico da aplicação dessa prática em uma sala aula. 


\section{Relato da Aplicação da Prática Complementar de se Ensi- nar/Aprender a História em uma Escola}

A aula que será exposta nessa parte do texto foi ministrada para alunos do oitavo ciclo da Escola de Educação Básica e Profissional da UFMG. Esse foi o primeiro contato deles com proposta pedagógica desta natureza. O nome real dos alunos será substituído por outros para não expô-los. A matéria ministrada aos alunos refere-se ao início do chamado Período Colonial do Brasil. Seguindo os passos supracitados na parte II desse artigo, traçamos os seguintes objetivos gerais: 1) Demonstrar que nas primeiras incursões dos portugueses ao que chamamos hoje de Brasil houve um estranhamento entre culturas diferentes que se encontravam - portugueses e índios do litoral. 2) Demonstrar algumas dessas diferenças culturais. 3) Demonstrar alguns dos principais motivos que levaram os portugueses a viajarem para tão longe. 4) Demonstrar como os índios podiam perceber os portugueses em seus primeiros contatos.

Para a fluidez do texto ${ }^{11}$, não será exposta a segunda etapa, a Criação de Situações de Aprendizagem, pois ela aparecerá na Exposição de Situações de Aprendizagem, a qual se passará a seguir. Antes de começar a exposição, é importante ressaltar que dividimos a sala em dois grupos, chamando a um dos grupos de "Portugueses" e outro de "Índios do Litoral". Logo depois iniciou sua exposição:

Professor ${ }^{12}$ : Vocês, o grupo dos portugueses, marujos que jamais viajaram por tanto tempo e tão longe, depois de uma longa temporada nave-

\footnotetext{
${ }^{11}$ Foram feitas anotações do processo. Não foi utilizado o recurso da filmagem ou gravação para não inibir os participantes. É relevante considerar a perspectiva etnográfica que marcou a experiência, considerando-se a sala de aula como ambiente relacional culturalmente organizado. A chegada de uma equipe profissional diferente gera, evidentemente, modificações na rotina do grupo social (sala de aula de história, com alunos e professor), reconfigurando as relações entre os sujeitos e suas relações com o conhecimento histórico. Estas observações ancoram-se teoricamente nos estudos de Marli André, que chama a atenção para a composição relacional de situações de pesquisa/intervenção que envolvem não somente uma observação da sala de aula, mas cria situações relacionais e intersubjetivas entre pesquisadores e alunos e professores. Nenhuma observação, nessa medida, é neutra, sobretudo em sala de aula. (André, 1995).

12 Vale destacar que os professores, tanto na experiência fictícia quanto na relatada, usam da narratividade para construção de ambiência histórica. Nesta narrativa comparecem descrição de paisagem, de intenções, divergências de interesses e também contextualização de processos presentes à época. Na medida em que a narrativa é confrontada com as visões
} 
gando pelo Atlântico se aportaram nas costas de uma terra que vocês conheciam só de ouvir falar, nunca desembarcaram nela. É verdade que no reino só se começou a falar dessa terra de uns tempos para cá, e os primeiros povoados que nela existiam, construídos por vocês, eram pouquíssimos. A embarcação de vocês levava alguns suprimentos para um povoado recém constituído, e depois deveria voltar para Portugal carregada com produtos da terra, como o pau-brasil muito valioso, e alguns animais e plantas. Por conta de uma tempestade do dia anterior, o navio de vocês acabou aportando longe do povoado que queriam desembarcar. Vocês tiveram que desembarcar ali mesmo, pois havia acabado os seus mantimentos e o navio necessitava de alguns pequenos reparos. Ao descerem na praia, viram diversos homens e mulheres de pele morena e nus que logo cercaram todos vocês. Eles falavam palavras que vocês jamais ouviram pronunciar e alguns tocavam o rosto de vocês, outros a vestes, outros tentavam pegar alguns objetos seus. Cercados por tanta gente e necessitando de mantimentos, 0 que vocês fizeram?

Gabriel $^{13}$ : Escondi dentro do navio.

Mariana: Eu segurei meus objetos para que eles não puxassem. Também não deixei que me tocassem.

Carlos: Fiquei falando "chefe" e apontando para o capitão do navio. "Quero falar com o chefe".

dos alunos, por meio de uma pergunta, será necessário agregar ponderações e mais informações para que os alunos consigam assumir posições. Consideramos que nas narrativas construídas pelos professores no processo de interlocução com os alunos comparecem elementos discursivos como analogias, metáforas, e comparações. Consideramos a natureza arbitrada destas narrativas, embora tenhamos vislumbrado aproximar o conhecimento histórico acadêmico do conhecimento histórico escolar. Consideramos também que as narrativas criadas no percurso da experiência devem ser compreendidas como exercícios imaginativos que vislumbram também a mesma prática por parte dos alunos. Por fim, gostaríamos de ressaltar que, no exercício imaginativo e narrativo criado, nós delineamos intenções dos personagens históricos, construímos perfis históricos. Contudo, como todo exercício imaginativo, embora orientado, há pontos que podem futuramente, ser corrigidos. Como na experiência está aqui narrada e descrita tal como ocorreu, preferimos mantê-la, mesmo apreciando pontos que podem ser alterados e aprimorados, sobretudo quanto ao perfil dos personagens indígenas (no plural) e portugueses, com suas culturas em movimento, contato e confronto em variados períodos históricos.

13 Embora se atribua a fala a um ou outro aluno, na maioria das vezes, era o grupo todo que falava. A opção por colocar a fala de um aluno em detrimento de outro é que alguns eram mais desinibidos para falar ao professor ou serviam-se melhor como porta-vozes. Disso decorre também avaliar que a experiência pode ser significativa mesmo para os alunos que dela não participam tão diretamente, mas, ao observarem, também se inspiram, aprendem, pensam.

História \& Ensino, Londrina, v. 2, n. 17, p. 257-282, jul./dez. 2011 
[Outros alunos deram outras opiniões nesse momento, mas foram anotadas somente algumas falas]

Professor: Mais alguém? Alguma ideia?

Gabriel: Eu voltei do navio e fiquei apontando pra minha boca, "COMI-DA"

Professor: Os índios continuaram a falar diversas palavras que vocês não entendiam, continuaram a apalpar vocês.

Mariana: Eu empurrei quem mexeu comigo, não quero que me roubem!

Professor: Como vocês estão percebendo o contato com os índios parece ter sido, em um primeiro momento, de difícil entendimento. São duas culturas diferentes que se encontram ${ }^{14}$. Vocês estão certos em querer conversar com o líder deles como também em procurar comida, pois estavam há muito tempo em alto mar se alimentando mal. Também estão certos em proteger seus objetos para que os índios não peguem, porque vocês consideram que pegar as coisas alheias sem permissão é roubar. Não é isso? Isso faz parte da cultura de Portugal. Mas para os índios, pegar os objetos do outro não é roubar. Os índios não tinham objetos como os europeus. Tudo pertencia a todos, todos podiam usar o que quisessem, não havia dono de nada. O que mais que os índios eram diferentes de vocês, portugueses? Já falei aqui antes outro dia.

[Vozes do Grupo]: Roupa, eles não usam roupa.

Professor: Isso também é uma diferença. Usar roupa era uma coisa da cultura dos portugueses, só que uns índios não tinham roupa, não se importavam com ela. Eles tinham uma espécie de tanga, tanto homens, quanto

\footnotetext{
${ }^{14}$ Anteriormente, havíamos explicado aos alunos que não havia uma cultura indígena e sim, culturas indígenas, no plural. Chamar povos de "índios" é uma maneira de homogeneizar grupos humanos que na verdade eram e são bastante heterogêneos. Portanto, o uso do termo "índio" sem levar em conta essas considerações pode levar o aluno a pensar que havia/há uma cultura indígena em oposição à portuguesa. Na nossa prática, utilizamos o termo "índio" apenas para fluidez da narrativa, mas não desconsiderando as diferenças supracitadas. O certo seria utilizarmos o nome de um grupo específico, como caetés, goytacazes, guaranis, etc, embora entre esses mesmos grupos houvesse também outras peculiaridades. Além disso, essa é uma discussão que remete também à permanência, na história, das culturas indígenas, em sua diversidade, com necessária compreensão da situação indígena no Brasil contemporâneo. Então, mesmo que a discussão feita durante a dinâmica relatada esteja situada no passado, ela também favoreceu e pode favorecer reflexões sobre a experiência contemporânea dos povos indígenas.
} 
mulheres, mas roupa mesmo eles não tinham. Por isso, que eles também podiam ficar provavelmente maravilhados em ver os portugueses com roupas $^{15}$.

Professor: Vamos continuar:

Depois de passarem algum tempo naquele lugar começaram a sentir saudades de casa. Na viagem, antes de chegar às terras dos índios, todos se conheceram e o que vocês tinham em comum era a pobreza. Antes de aprenderem a arte de navegar, muitos de vocês não tinham ofícios em suas terras, pertenciam a famílias numerosas que quando muito, garantiam somente um pouco de comida para vocês. Alguns queriam casar, e para isso era importante ter algum pouco de dinheiro, senão os pais da noiva não permitiam o casamento. Mas como disse, todos vocês eram de origem muito pobre. Por isso pergunto aos portugueses: o que vocês vieram fazer aqui, tão longe de casa?

Carlos: Ué, igual o senhor falou, eu quero é ficar rico, viajar, comprar tudo que eu puder!

Gabriel: Eu já quero morar no Brasil!

Mariana: Os portugueses vieram para o Brasil para ficarem ricos, queremos ouro!

Henrique: Eu quero pegar um bronze.

[Outras opiniões nesse momento são dadas]

Professor: É mais ou menos o que muitos de vocês falaram. Os portugueses viajavam para lugares distantes, justamente, em busca de riqueza fácil para eles mesmos, mas também para o rei. A maioria não queria morar no "Brasil", porque a distância de Portugal era imensa, além de sofrer constantes atritos com os índios e da terra faltar dos artigos que os portugueses estavam acostumados a ter. Se você queria uma tesoura, dificilmente conseguiria, tinha que vir de navio. Se você precisasse extrair um dente não ti-

15 Devemos ressaltar que deveríamos ter explorado mais sobre a "nudez" dos índios. Sabese que as diversas culturas que habitavam o que hoje chamamos de Brasil se relacionavam de diferentes maneiras com sua nudez/ seus corpos. As roupas que os portugueses utilizavam eram diferentes, é verdade, mas não significa que os povos indígenas não utilizassem nenhum objeto em seu corpo. Contudo, uma discussão que pode ser feita é que pela tropicalidade do clima o excesso de vestimentas era algo impensável para os indígenas. Outra, ainda, diz respeito à análise das diferenças culturais relacionadas à cultura corporal, o que certamente envolverá reflexões e descentramentos importantes. 
nha o dentista, que era chamado nessa época de cirurgião. Se você queria comer queijo, não tinha nem vaca para dar leite. Ou seja, os portugueses queriam passar o menor tempo possível no Brasil e enriquecer vendendo os produtos que aqui tinham. Mas eles não queriam somente riqueza. O que vocês, portugueses católicos e fiéis a deus também queriam? Nós já falamos disso em sala de aula.

Turma: (Silêncio)

Carlos: Queria fazer capitania, dividir as terras.

Alice: Tinha aquele lance de "capitania" de Jesus.

Professor: Fala é da Companhia de Jesus. Então, além de enriquecerem, o que vocês querem?

Mariana: Nós queremos colocar uma Companhia de Jesus na terra e ensinar os índios a amar Deus.

Professor: Por quê?

Mariana: Para eles conhecerem Deus, ué.

Professor: Mais ou menos. A Companhia de Jesus era uma ordem dentro da igreja católica que tinha por objetivo catequizar os povos fora da Europa na religião católica. Eles eram chamados até de soldados de Jesus Cristo, pois eles iam muito longe para propagar a fé. Então, eles não queriam instalar uma companhia, não é uma empresa, eles queriam vir para o Brasil para ensinar os índios a serem cristãos, a conhecer a palavra de deus. Quem era dessa ordem religiosa, quem ensinava, era chamado de Jesuíta. Os jesuítas catequizavam não só na América, como também na África e até na China e Japão. Então para todo lugar que vocês, portugueses, iam, vocês queriam riquezas, para si e para o rei, e a conversão dos povos para o catolicismo. Essas riquezas que eu estou falando não é só de achar algo precioso, mas a própria troca, o comércio, levava à riqueza. Vocês não lembram que eles queriam ir para as Índias e lá compravam as especiarias para vender na Europa? No início, vocês até queriam comercializar com os índios, mas os índios não tinham muitas coisas que vocês tinham interesse. Quanto à conversão dos povos para o catolicismo, vocês acreditavam que dessa forma estavam agradando a deus, atraindo novas almas para a sua fé. Mas vocês não podem esquecer que os índios também tinham seus deuses. Não 
há religião certa nem errada. A de vocês não é melhor que a do índio, só porque o índio não acredita no seu deus. Cada cultura tem uma forma de se perceber e perceber o mundo. Os índios acham que deus é o sol, os portugueses que há um deus semelhante a ele no céu, o fulano acredita que deus é um homem com cabeça de cachorro, e por aí vai, cada cultura tem um deus diferente. Voltando, agora me digam, senhores dos mares, o que vieram fazer distante de Portugal?

Carlos: Viemos levar a fé para os índios, procurar riquezas.

Mariana: Riquezas para nós e para o rei.

Professor: Isso. Agora esperem um pouco que vai ser a vez deles aqui, dos índios. Prestem atenção. A situação agora é outra, esqueçam esses portugueses daqui.

Todas as vezes que ficava muito quente, toda a aldeia se levantava e mudava para um lugar mais ameno. E quando ficava muito frio, vocês voltavam para lugares mais quentes. Não tinham morada fixa, mas quando se estabeleceram na "mata colorida", que era como vocês chamavam um lugar que costumavam morar por algum tempo, escutaram uns barulhos vindos do mar, e quando viram eram duas canoas imensas navegando pela costa. Vocês ficavam imaginando que tamanho teria a árvore que derrubaram para fazer tamanha canoa. Depois de um tempo elas pararam e delas saíram umas canoas menores, quase do tamanho daquelas que vocês usavam. Quando, enfim, elas chegaram à praia, saíram uns homens esquisitos, com o corpo todo coberto com umas palhas que vocês nunca viram, algumas de outras cores. Também tinham muito cabelo e falavam diferente. Eram muito pálidos. Vocês ficaram curiosos para conhecer melhor aquele povo que tinha canoas muito grandes. Resolveram levar todos à aldeia e lá vocês deram comida e abrigo a eles. Passaram-se vários dias e eles continuavam na aldeia, pareciam gostar muito de vocês, o chefe da aldeia chamava-os de amigos. Vocês aprenderam a falar algumas palavras da língua deles, mas eram eles que se empenhavam em aprender a de vocês. Diziam que eram de um povo chamado "portugueses". Depois a lua mudou mais umas três vezes de face e eles continuavam lá. Todos estavam contentes com aquele povo diferente. Mas certo dia, eles disseram que precisavam ir para sua ter- 
ra que era do outro lado do mar. Perguntaram se os amigos índios não poderiam ajudá-los a cortar umas árvores, só algumas para eles levarem para suas canoas gigantes e depois levarem para suas terras. O que vocês responderam aos seus amigos?

Saulo: Eu não ajudei, eles vêm comer e dormir nas minhas custas e ainda querem que eu fique carregando madeira? Eu não!

Ana: Eu também não.

Tiago: Não ajudei, não vamos ajudar no desmatamento. Somos índios, nossa casa é a floresta.

Professor: Vejam bem. Vocês não estão sendo coerentes. Eles são seus visitantes, vocês gostaram deles. Vocês têm que ter um bom motivo para não ajudá-los e até agora vocês não falaram nenhum.

Saulo: Mas aí o senhor quer que a gente faz uma coisa que não queremos. Eles vão nos explorar.

Professor: Vocês não tinham ideia do que os portugueses podiam fazer com vocês, não sabiam que eles queriam explorar, vocês precisam agir como se não soubessem, como se fizessem parte das primeiras aldeias que entraram em contato com os portugueses. É a primeira vez que vocês veem aqueles homens esquisitos. Agora se eles derem brecha aí vocês podem mudar de opinião. Então, o que vocês fizeram?

Saulo: Ué, então fomos ajudar né, fazer o quê?

Professor: Todos estão de acordo que vocês têm de ajudar os portugueses porque não sabiam como eles eram, como eles agiam?

[Vozes do grupo]: Estamos!

Professor: Se vocês quiserem fazer outra coisa pode, mas têm que ser coerentes. Tem que ser o que os índios poderiam fazer, tem que ter a ver.

[Até aqui podemos tecer algumas considerações. Primeiro, os estudantes, no início têm dificuldades de se ambientar com o tema. Porém, à medida que esse exercício se torna frequente, os alunos começam a se ambientar mais rápido e a interpretar conforme a época. Segundo, eles cometem anacronismo ao não aceitar, nessa situação de aprendizagem, ajudar os portugueses, porque já apreciam e ponderam o mal da História desse período. O professor age então para que eles tentem pensar como se não tives- 
sem conhecimento do futuro. Esta é uma das maneiras de exercer empatia histórica, favorável ao descentramento. Terceiro, o aluno percebe que o professor quer que eles sigam um determinado enredo, mas logo em seguida, o docente demonstra que o grupo não pode se negar a ajudar os portugueses se não tiverem um motivo convincente, pois não estão sendo coerentes com aquele momento histórico. Os alunos acabam se convencendo e aceitam a proposta do professor. Porém, como é a primeira vez que os alunos se deparam com esse tipo de abordagem, ainda incorrerão no anacronismo.]

Professor: Depois de encherem um navio, vários dias seguidos, os portugueses acharam muito boa a ajuda de vocês e agradeceram aos amigos, disse eles: Nós agradecemos em nome do Rei de Portugal a estimada ajuda dos amigos índios.

Saulo: Agradeceram? Ué, e quanto que eles pagaram para gente? Pergunta para ele quanto que eles vão pagar para a gente.

Professor: Você mesmo pode perguntar isso para ele, ele não está te agradecendo? Interaja com ele.

Saulo (olhando como se o professor fosse um português): Aqui eu não trabalho de graça, quero que você me pague.

Professor: O que a turma acha disso? Ele pode cobrar dos portugueses por ter carregado as árvores?

[A turma fica pensativa]

Saulo: Isso não é justo, eu trabalho o dia inteiro e ganho só obrigado?

Tiago: Não, "véio", mas índio não mexia com dinheiro. Índio nem sabia o que era dinheiro.

Saulo: Não, eu quero receber!

Professor: O Tiago tá certo. O dinheiro português não tinha função nas culturas indígenas da época. Por isso, no início não se pagava. O que você faria com as moedas de ouro que o português te pagasse? O que você iria comprar? Você quer ganhar uma coisa que você não precisa. Nesse caso, vocês não se importavam em ajudar, pois estavam ajudando amigos, embora não soubessem o que eles fariam com aquele monte de árvore. Mas vamos continuar a história:

História \& Ensino, Londrina, v. 2, n. 17, p. 257-282, jul./dez. 2011 
Depois dessa ajuda, os portugueses foram embora levando as árvores. Porém, todos os anos eles vinham na mesma época, com maior número de canoas gigantes e vocês tinham que ajudar sempre. Vocês demoravam mais tempo agora para carregar tantas árvores e precisavam de maior quantidade de homens da aldeia. Houve uma vez que todos tiveram que ajudar, inclusive as mulheres. No último ano, vocês se recusaram a carregar tantas árvores e os seus amigos portugueses prenderam alguns de vocês, inclusive o chefe e o pajé, e deram chicotadas em outros. Disseram que só libertariam os presos, se vocês terminassem de carregar as canoas gigantes. Vocês terminaram e eles libertaram todos, mas antes, chicotearam os prisioneiros, para que não esquecessem que sempre terão que ajudar. Este ano, os portugueses chegaram até mesmo antes da época que costumavam vir. O mar ficou coberto de canoas gigantes. Alguns portugueses chegaram com uns paus que cospem fogo, que vocês nunca virão na floresta, e chicote, dizendo que amanhã, toda a aldeia teria que ajudar no carregamento. Depois que eles partiram, vocês viram que o pajé foi pedir conselhos aos espíritos ancestrais, enquanto o chefe reuniu todos os homens da aldeia para decidirem o que vocês vão fazer. Ele disse: na época de nossos antepassados, não tínhamos que derrubar árvores e nem conhecíamos eles. Agora, sempre temos que ajudá-los. O que vocês me aconselham a fazer?

Como era um conselho de guerreiros, só os homens participavam, as mulheres do grupo não vão poder opinar. Vocês são as índias e estão cuidando das crianças. Depois falo para vocês como que era a vida em uma aldeia. Qual era o papel de cada um. Mas só os meninos do grupo, o que vocês decidem?

Saulo: Agora não é possível. Não vou mesmo. O trabalho tá acabando com minhas mãos e com a minha coluna.

Ana: Paramos "total". Não quero trabalhar por nada.

Marcos: Mas e se eles baterem na gente?

Saulo: Ué, somos a maioria, vou chamar todo mundo pra fazer a revolução, ninguém vai trabalhar em serviço pesado.

Professor: É por aí mesmo. No início os índios não conheciam os portugueses, toleravam, e a maioria era pacífica. Mas com essa quantidade de 
trabalho imposta pelos portugueses, algumas aldeias começaram a não aceitar. Pois então, qual é a proposta de vocês ao chefe?

Saulo e Ana: Que não vamos trabalhar.

Professor: Agora vamos supor que o grupo aqui da sala dos portugueses, seja esse mesmo que está obrigando vocês a carregarem as pesadas árvores. Agora é a vez deles atuarem. Quero saber o que vocês, portugueses, farão. Vocês estavam acostumados a colocarem os índios para trabaIharem, carregarem pesadas árvores para os navios. Porém, um dia atrás, chegou um índio dizendo que o chefe deles havia decidido que os índios não iriam mais trabalhar. E aí?

Carlos: Descer o pau nesses preguiçosos. Peguei a espingarda, vou dar tiro neles tudo.

Henrique: Eles são loucos se não trabalharem, vão morrer. Não é possível que eles não têm medo da morte do pau de fogo.

Professor: Pois é, vocês não decidiram. Quero uma decisão do grupo. Pensem bem, eles não querem carregar os navios e vocês precisam dessa valiosa mercadoria para vender na Europa. Alguém do grupo dos índios fala para o grupo dos portugueses que vocês não vão trabalhar, explique o porquê. O grupo dos portugueses pode escolher alguém para responder ao índio.

Saulo: Não vamos trabalhar porque vocês nos exploram. Não precisamos de trabalhar, tudo tá na natureza. Já estou ficando todo machucado de ajudar vocês a carregar árvores. Não precisamos de árvores. Vocês que precisam, então vocês carregam.

Carlos: Se vocês não trabalharem é chumbo, não vai sobrar ninguém. Podem escolher ou trabalham ou morrem.

Saulo: Somos um monte, vocês uns poucos. Se vocês tentarem isso vocês é quem vão morrer.

Professor: Como vocês estão percebendo, depois de algum tempo em contato com os portugueses, os índios não queriam mais fazer esse árduo trabalho. Os portugueses, por seu lado, sabiam que tinham poder para obrigá-los a trabalhar. Mas vocês acham que os índios vão ficar parados? Ao longo da história, os índios não ficaram parados aceitando tudo o que os 
portugueses falavam. Eles também resistiam, atacavam. Durante o período de colonização portuguesa, haverá choque entre essas culturas. Haverá embates, derramamento de sangue, força. Agora nem sempre acabava em guerra. Para evitar confrontos, os portugueses também negociavam. O grupo dos portugueses também pode negociar e evitar as mortes de ambos os lados. Como vocês sabem, os índios não se interessam, a princípio, por ouro. Mas os portugueses podem oferecer outros objetos que eles possam se interessar em troca do trabalho, ou outro tipo de negociação da cabeça de vocês. Enfim, vocês tem outras alternativas para evitar o confronto. O português nem sempre resolvia tudo na pólvora, não. Às vezes, eles também ponderavam, afinal, era a vida deles que estava em jogo. Agora que eu já dei esse monte de dica, vocês podem continuar a conversa. Vamos fazer assim, o que vocês decidirem nessa conversa é o que vai acontecer com ambos os grupos, beleza?

Saulo: Então, não vamos trabalhar, não precisamos e não queremos.

Carlos: Se vocês não ajudarem vocês vão morrer.

(Cochicho entre o grupo dos portugueses)

Carlos: Vamos fazer então o seguinte. Ninguém briga com ninguém. Ao invés de vocês trabalharem todos os dias para nós, vocês trabalham a metade dos dias e pronto, está resolvido. Não atacamos vocês e vocês podem fazer o que quiser.

(Grupo dos Índios discute)

Saulo: Não, ainda achamos muito, antes não trabalhávamos nada, agora temos que trabalhar. Não precisamos.

Carlos: Mas vocês sabem que vão morrer se não trabalhar, não vamos aceitar.

Saulo: Então vai ter guerra.

(Grupo dos Portugueses discute)

Carlos: Então vamos fazer assim: Vocês trabalham metade dos dias e nós ainda vamos dar várias coisas para vocês: anzol, linha, panela, espelho, vidro, faca.

Saulo: Não queremos lixo. 
Clara: Espera aí. Isso não era lixo, nós gostávamos dessas coisas, porque não tínhamos. Eu li que os portugueses davam essas coisas para nós e a gente "curtia".

Saulo: É? Então espera aí.

(Grupo dos índios discute)

Saulo: Pode ser, vamos trabalhar dia sim e dia não. O preço é duas, não, três coisas de cada coisa que você falou a escolha do índio que trabaIhar.

Carlos: Professor, isso é muito caro para gente?

Professor: Não, barato.

Carlos: Então tá, pode ser.

Professor: Então terminou assim: vocês negociaram e evitaram a guerra. Como eu já tinha falado, também havia negociações com os índios, ainda que os portugueses tivessem armas de fogo para obrigá-los e também podiam escravizá-los.

\section{Considerações Finais}

Como todos os recursos metodológicos, esse também tem suas limitações. Por exemplo, o tempo que o professor despende criando as Situações de Aprendizagem é bem maior do que aquele que gastaria para elaborar uma aula tradicional (pelo menos, nas primeiras vezes que não está familiarizado com o procedimento). Além disso, é importante que o professor de História tenha algumas habilidades que facilitem a implementação de tal procedimento, tal como o conhecimento do tema, facilidade na escrita e, como ficou evidente ao longo do texto, uma boa capacidade de intermediação entre os alunos e as Situações de Aprendizagem. Na ausência dessas habilidades, justificar-se-ia, como desdobramento desse projeto, a criação de um material de apoio ao professor, com temas, objetivos e Situações de Aprendizagem pré-definidas, bem como dicas para ambientar os alunos a cada contexto, mediações em cada circunstância, mesmo sabendo que este recurso metodológico requer o contato com o inusitado. A participação dos 
alunos também é imprescindível. Sem ela a aula não acontece, pois necessita das repostas dos alunos aos problemas propostos. Outra peculiaridade desta estratégia metodológica é que ela requer que o aluno tenha a mínima noção do tempo em que estão estudando. Sem esse conhecimento prévio, por menor que seja, o aluno fica limitado para explorar o mundo de possibilidades que o professor propõe. Por outro lado, se bem desenvolvida a experiência também pode surtir significativos efeitos sobre o aprendizado histórico em uma sala de aula. Dessa mesma classe que lecionamos, as reações que observamos foram, primeiramente, a facilidade em ambientar nos tempos históricos propostos, a entenderem melhor as Situações de Aprendizagem.

Vale destacar, da experiência vivenciada, que as formulações dos alunos - tanto os portugueses quanto os indígenas - foram marcadas pelo exercício da assunção de pontos de vista que, neste caso, estavam em confronto na maior parte das vezes. Notamos que a partir de determinado momento da experiência os alunos assumiram o diálogo entre portugueses e indígenas (em português, evidentemente) sem que o uso da língua portuguesa, para a situação vivenciada, fosse por eles em nenhum momento questionada. Vale também notar que, em momento de dúvida um aluno interrogou o professor - [é muito caro para a gente?], o que denota o papel atribuído ao professor, no processo pedagógico vivido, como um profissional capaz de elucidar problemas e situações históricas e interpretar e apreciar a correção das posições assumidas.

A maioria dos alunos conseguia, empaticamente, adentrar no período estudado, imaginar que viviam determinada época, enfrentando problemas daquele tempo. Os anacronismos também foram diminuídos, enquanto as participações dos alunos em sala de aula aumentaram significativamente. Também houve notória desinibição por parte dos discentes em opinar nas ações que os grupos deveriam tomar. Estavam também mais motivados. Não foram poucas as vezes que ouvimos os alunos dizerem, ao terminar a aula, que não sentiram o tempo passar. Outra observação, talvez a mais importante, é que os alunos ficaram bastante interessados nas aulas, pres- 
tando maior atenção ao desenrolar do enredo que o professor propunha. Pareciam sentir que, de fato, eram personagens daquela História.

\section{Referências}

ANDRÉ, M. E. D. A. de. Etnografia da Prática Escolar. Campinas: Papirus, 1995.

BARBOSA, A.; GONÇALVES, C.; MACHADO, E.; OLIVEIRA, E. O trabalho infantil no século XIX: uma visão de alunos. In: MELO, M. do C.; LOPES, J. M. (Org.). Narrativas Históricas e Ficcionais: recepção e produção para professores e alunos. Minho: Universidade do Minho, 2004.

BITTENCOURT, C. M. F. Ensino de História: fundamentos e métodos.. São Paulo: Cortez, 2005.

BLOCH, M. Apologia da história, ou o ofício do historiador. Rio de Janeiro: Jorge Zahar, 2001.

CHARLOT, B. Relação com o saber, formação de professores e globalização: questões da para educação hoje. Porto Alegre: Artmed, 2005.

FERREIRA, A. ; DINIS, C. ; LEITE, Eduarda. A vida quotidiana em Roma na Época Imperial: narrativa de alunos. In: MELO, M. do C. ; LOPES, J. M. (Org.). Narrativas Históricas e Ficcionais: recepção e produção para professores e alunos. Minho: Universidade do Minho, 2004.

KARNAL, L. (Org.). História na Sala de aula: conceitos, práticas e propostas. São Paulo: Contexto, 2003.

LAVILLE, C. A guerra das narrativas: debates e ilusões em torno do ensino de história. Revista Brasileira de História, São Paulo. v. 19, n. 38, 1999.

LE GOFF, J. História e memória. Campinas: Ed.Unicamp, 2003.

LEE, P. J.; ASHBY R. Empathy, Perspective Taking, and Rational Understanding. In: DAVIS, O. L.; YAGER, Elizabeth A.; FOSTER, S. J. Historical empathy and perspective taking in the social studies. Lanham, MD: Rowman and Littlefield, 2001.

MELO, M. C. ; PEIXOTO, R. A Troca de Correspondências: a imaginação e as fontes históricas. Narrativas Históricas e Ficcionais: recepção e produção para professores e alunos. Minho: Universidade do Minho, 2004.

MELO, M. C. Eu sou escritor de H(h)istória(s)! - as competências de leitura e escritura e a aprendizagem de $\mathrm{H}(\mathrm{h})$ istória. In: Como pôr os alunos a tra-

História \& Ensino, Londrina, v. 2, n. 17, p. 257-282, jul./dez. 2011 
balhar? experiências formativas na aula de português. Lisboa: Lisboa Ed., 2003.

ROSANVALLON, P. Por uma história conceitual do político. Universidade Estadual Paulista, 1996.

WINEBURG, S. S. The Cognitive Representation of Historical Texts. In: LEINHARDT, G.; BECK, I. L.; STAINTON, C. Teaching and Learning in History. New Jersey: Lawrence Erlbaum Associates, 1994.

YILMAZ, K. Historical Empathy and Its Implications for Classroom Practices in Schools. The History Teacher 40.3 (2007): 10 pars. Acesso: 17/10/2010. <http://www.historycooperative.org/journals/ht/40.3/yilmaz.html>. 